\title{
Short bowel syndrome: Intestinal adaptation and medical therapy
}

\author{
W DONALD BUIE, MD, OLIN G THURSTON, MD, RICHARD N FEDORAK, MD
}

\begin{abstract}
Short bowel syndrome is a clinical entity, a consequence of significant loss of intestinal surface area, and manifests a variable picture of diarrhea, steatorrhea, malabsorption and weight loss. Previously high mortality rates have been reduced by the early use of parenteral nutrition and have subsequently resulted in increased survival and prevalence of the condition. Ultimate patient survival is dependent on the intrinsic adaptive ability of residual intestine and this, in turn, is dependent upon length, type, functional state and the presence or absence of an ileocecal valve. The mechanisms of intestinal adaptation are not entirely understood; however, they can be grouped into three broad categories: luminal nutrition, hormonal factors, and pancreaticobiliary secretion. Medical treatment of short bowel syndrome remains supportive and centres around the control of three pathophysiological defects: decreased intestinal transit time, gastric hypersecretion, and reduced functional mucosal surface area. Can J Gastroenterol 1990;4(2):70-78
\end{abstract}

Key Words: Intestinal adaptation, Intestinal resection, Medical therapy, Short bowel syndrome

\section{Syndrome de l'intestin court: Adaptation intestinale et thérapie médicale}

RESUME: Le syndrome de l'intestin court est une entité clinique résultant d'une perte importante d'un segment de l'intestin; il présente un tableau variable de diarrhée, de stéatorrhée, de malabsorption et de perte pondérale. Le recours rapide à l'alimentation parentérale a réduit les taux de mortalité tout d'abord

Departments of Surgery and Medicine, University of Alberta, Edmonton, Alberta Correspondence and reprints: Dr Richard N Fedorak, University of Alberta, Department of Medicine, Division of Gastroenterology, 519 Robert Newton Research Building, Edmonton, Alberta, T6G 2C2. Telephone (403) 492-6941

Received for publication March 23, 1989. Accepted December 12, 1989
$\mathrm{S}_{\mathrm{s}}^{\mathrm{u}}$ URGICAL TREATMENT OF MANY gastrointestinal diseases neces. sitates resection of segments of small intestine. This is well tolerated in most cases due to the intrinsic reserve of the gastrointestinal tract. However, massive intestinal resection can lead to a variable clinical picture of diarrhea, steatorrhea, malabsorption and weight loss. This constellation of clinical events has been termed 'short bowel syndrome' and has been recently reviewed $(1,2)$.

The disease states which predispose to massive intestinal resection are determined primarily by the age of the patient. The infant population must contend with necrotizing enterocolitis, atresias, volvuli and abdominal wall defects with resultant herniation and vascular compromise $(3,4)$. The adult is more likely to be faced with repeated resection as a consequence of Crohn's disease (5), while in the elderly, resection is most likely due to mesenteric infarct (6).

In the past, there has been a high mortality rate associated with short bowel, and thus, short bowel syndrome 
élevés, et a entraîné une augmentation de la survie et du nombre de cas de cette affection. La survie ultime du patient dépend de la capacité intrinsèque d'adaptation du segment d'intestin préservé, laquelle capacité dépend à son tour de la longueur, du type, de l'état fonctionnel et de la présence ou non de la valvule iléo-caecale. Les mécanismes d'adaptation intestinale ne sont pas entièrement compris mais peuvent toutefois être classés en trois grandes catégories: la nutrition au niveau des lumières, les facteurs hormonaux et la sécrétion pancréaticobiliaire. Le traitement meédical du syndrome de l'intestin court consiste surtout à apporter un soutien au patient et s'attache à contrôler trois problèmes physiopathologiques: la diminution du transit intestinal, l'hypersécrétion gastrique et la réduction de la surface fonctionnelle de la muqueuse.

was an extremely rare entity $(7,8)$. Development of improved supportive care and total parenteral nutrition have prolonged survival and made this condition prevalent $(4,9-11)$. Parenteral nutrition has allowed continued intravenous feeding during intolerance to oral nutrition, and patients with extremely short bowel can now exist entirely on home total parenteral nutrition $(12,13)$.

Although it is well known that residual small bowel length below 50 $\mathrm{cm}$ makes maintenance of adequate nutrition difficult, the minimal length of small intestine compatible with life (withuat nutritional support) is poorly defined. In the early 1950 s it was believed that survival with less than one half of the small bowel length was improbable $(7,8)$. This was quickly challenged by reports of patients surviving with shorter and shorter lengths of bowel (14-16). The first comprehensive study of short bowel syndrome in children was published in 1972 by Wilmore, in which he reviewed the outcome of 50 infants (17). He found that survival depended to a large extent on the presence or absence of the ileocecal valve in addition to residual intestinal length. Infants with greater than $38 \mathrm{~cm}$ of small bowel and an ileocecal valve had $100 \%$ long term survival, while those with 15 to $38 \mathrm{~cm}$ had only $50 \%$ survival. Infants with less than $15 \mathrm{~cm}$ of bowel had $100 \%$ mortality regardless of the status of the ileocecal valve. In the absence of an ileocecal valve, $40 \mathrm{~cm}$ of residual bowel was the lower limit for any degree of survival.

The next most important determinant of the clinical picture following small bowel resection is intrinsic intes- tinal adaptation (18). Intestinal adaptation is felt to be influenced by three factors: the type of intestine that remains; the disease state for which the resection was necessary; and the condition of the residual intestine $(1,2)$.

Presently, treatment of the short bowel syndrome can be divided into two general categories: supportive therapy and therapy to enhance intestinal adaptation. Most treatment measures, whether medical or surgical, are supportive in nature while awaiting intrinsic intestinal adaptation. Recent developments suggest that some modes of therapy may enhance or accelerate intestinal adaptation.

This review will first examine intestinal adaptation following the stimulus of small bowel resection. It will then examine medical therapy for the short bowel syndrome. For the purpose of this discussion, a strict definition of short bowel syndrome as defined by length or percentage of bowel resected will be avoided because of the extreme variation in function of patients with similar residual lengths (2). The definition used will be a clinical one in which the signs and symptoms outlined above are present.

\section{INTESTINAL ADAPTATION}

Intrinsic intestinal adaptation may be the single most important variable affecting the eventual outcome of a patient with short bowel syndrome. It, in turn, is dependent upon four factors: the length, type and functional state of the residual intestine, and concomitant colonic and ileocecal valve resection, both of which are detrimental to adaptation (1).

It has been shown clearly by Hanson et al (19) that the adaptive intestinal response is directly related to the amount of intestine resected, and clinical studies have confirmed this (4, $14,17,20)$. This adaptive response can be overwhelmed by massive intestinal resection (18). Residual ileum is much more efficient and effective at intestinal adaptation than jejunum, although the mechanisms involved are not entirely clear $(18,21,22)$. If the residual intestine is affected by an active disease process such as Crohn's disease or diffuse arteriosclerosis, intestinal adaptation may also be inhibited.

Adaptation is also a function of time, and in humans it is generally accepted as continuing for up to two years following small bowel resection $(1,2,23)$. The definitive effects of medical or supportive therapy cannot be evaluated until after this time.

Intestinal adaptation can now be discussed from two viewpoints: morphological and functional. Original descriptive studies of intestinal adaptation were done from a morphological viewpoint only and it has been only in the past 20 years that functional studies have been performed to complement them.

Morphological adaptation: Macroscopic changes following intestinal resection have been recognized since the classical experiments of Senn in 1888 (24) and Flint in 1912 (25), and have been confirmed by many subsequent studies (26-31). Residual intestine undergoes dilation and thickening of all of its layers (29). However, whether or not there is a true increase in bowel length is controversial and may, in part, be attributed to the different animal models examined. Most authors believe that an increase in intestinal length is not part of the morphological adaptive response in humans $(18,21,32)$.

The microscopic picture of intestinal adaptation has also been well described. Flint in his classic paper (25), demonstrated that the intestinal villi doubled in height, and while he calculated a fourfold increase in mucosal surface area, he correctly observed that the number of villi remained constant and 
crypt depth increased. Subsequent studies have confirmed these observations (26-34).

Mucosal hypertrophy is maximal just distal to the post resectional anastomotic site and decreases further downstream (28). Although distinct mucosal hyperplasia occurs proximal to the anastomosis, it is far less pronounced. Jejunal resection produces a 70 to $100 \%$ increase in structural and functional measurements in the residual ileum, whereas ileal resection produces only 20 to $30 \%$ increases in structural and functional measurements in residual jejunum (27,28,32-35).

Functional adaptation: The morphological adaptations observed likely contribute to functional adaptation. These functional alterations can be separated into changes in absorption and motility.

The loss of mucosal surface area reduces the absorption sites of almost all nutrients and, as a consequence, functional adaptation is seen involving the absorption of most nutrients $(21,33)$. There is increased segmental absorption of fluid and electrolytes (36). Oligosacch arides and monosaccharides are absorbed at increasing rates when absorption is expressed per length of intestine $(21,31,37)$. Thus it appears that absorption can be induced, suggesting the possibility of receptor recruitment $(38,39)$.

Brush border enzymes also show adaptive changes with increase in total activity per segment; however, the specific activity of the enzymes is not altered and may even decrease in vitro $(38,40)$. It has been suggested that brush border membrane enzymes may be induced earlier along the villus so that enterocytes are functional at an earlier stage of development $(29,41)$. Recently, however, studies by Menge and Chaves (42) on disaccharidase activity in post resectional rat mucosa showed maintenance of the normal enzymatic gradient along the villus and emphasized that the cells are probably not functional immature cells. The function of individual enzymes may be more dependent on the total enzyme activity levels in the residual segments prior to resection, as specific enzyme systems are not uniformly distributed throughout the bowel. Despite these changes in brush border enzymes, the lipid composition (total free fatty acids, total bile acids, total cholesterol, total and individual phospholipids, and the ratio of total phospholipids to total cholesterol) of brush border membrane was found to be similar in control resected intestine (43).

Adaptation to the absorption of amino acids and peptides also occurs following intestinal resection. The brush border becomes much more efficient at protein utilization, increasing both absorption and peptidase activity as expressed per unit length $(21,33,38)$. Again, this is probably secondary to mucosal hyperplasia (41).

Adaptation to lipid digestion and absorption is more difficult to assess due to the confounding problem of bile acid pool losses. It appears that there is an increase in the absorption of free fatty acids, mono- and diglycerides per unit length of residual intestine (21).

As seen with the morphological adaptive response to intestinal resection, the functional adaptive response of the ileum is greater than that of the jejunum. In the normal intestine, jejunal absorption of nutrients is greater than the ileum. With jejunal resection, the ileum adapts to absorb nutrients at nearly the same or increased rate relative to normal jejunum (44). Following ileal resection, residual jejunum undergoes a small degree of adaptation. The increase in absorptive function is not as marked and it cannot assume the specialized ileal functions of bile salt and vitamin $\mathrm{B}_{12}$ absorption $(21,33)$. Interestingly, as ileal enterocytes undergo adaptive hyperplasia, there is a supranormal absorption of both vitamin $B_{12}$ and bile acids as expressed per unit length of intestine, although this appears to be of little clinical consequence (21).

As the major cause for malabsorption in the short bowel syndrome is the loss of mucosal surface area, the morphological changes of adaptation to increase the residual surface area are understandable. Similarly, maintaining the functional capacity of the short gut requires that the intestine absorbs more per unit length. Clinically, functional adaptation is observed as the patient with short bowel syndrome slowly recovers tolerance to oral feeds with diminishing diarrhea and steatorrhea $(1,2,18)$.

The second functional adaptation involves intestinal motility. Transsection of the proximal bowel separates the duodenal pacemaker from the residual intestine (45). Uncoordinated peristal. sis, combined with dilation of the intestine leads to ineffective forward propulsion and mixing. This results in bacterial overgrowth, impaired mixing of chyme, poor digestion and alteration in transit time.

There is recent evidence that the ileum acts as a brake on proximal intestinal transit. Initial studies by Snell (46) first described the association between steatorrhea and small bowel hypomotility. In a recent experiment, Spiller et al (47) demonstrated that the instillation of fat into the ileum caused a delay in transit time of jejunal contents (47). The effect was not seen with the instillation of either carbohydrate or protein solutions. This may further explain why jejunal resection is clinically better tolerated than ileal resection, as a residual ileal segment can still exert this braking effect on intestinal transit.

\section{MECHANISMS OF ADAPTATION}

How does intestinal adaptation occur? There is no single theory which explains all of the experimental evidence. Three major factors proposed are: luminal nutrition, hormonal or systemic factors, and pancreaticobiliary secretions.

Luminal nutrition: Evidence for the importance of luminal nutrition in the adaptive response following resection is best illustrated in three situations. When luminal nutrition is withheld by starvation, with or without maintenance of parenteral nutrition, the intestinal mucosa atrophies $(48,49)$. This intestinal atrophy can be reversed by the reinstitution of oral nutrition (50). Second, exclusion of the intestine from the luminal stream by creation of Thiry. Vella fistulas, or with intestinal bypass, 
causes atrophy in the defunctioned intestine $(44,51)$. Furthermore, Jacobs et al (51) showed that the institution of elemental Vivonex (Norwich-Eaton) solution into a Thiry-Vella fistula not only prevented atrophy but induced mucosal hypertrophy. Third, transplantation of the ileum to a more proximal position in the gut exposes the ileum to a greater volume of luminal nutrients with a resultant ileal mucosal hypertrophy and functional adaptation. The jejunum which is now lying downstream from the ileum undergoes slight hypoplasia (52).

The relative importance of luminal nutrients in the adaptive response to resection is unknown. Studies by Morin (53) in rats showed that the oral infusion of only $20 \%$ of the total daily caloric requirements as long chain triglyceride fat prevented intestinal atrophy in rats maintained on parenteral nutrition. Protein and carbohydrate when infused in a similar manner had only a partial sparing effect.

Whether the effect of luminal nutrients on intestinal adaptation is mediated directly or indirectly through paracine or endocrine responses remains to be determined (54).

Hormonal factors: Not all facets of intestinal adaptation are adequately explained by the effects of luminal nutrition. Mucosal hyperplasia proximal to an anastomosis and the hypertrophic effect of intestinal resection on a previously constructed ThiryVella loop suggest that other mechanisms must be present $(28,55)$.

Perhaps the strongest evidence for the existence of humoral factors is the parabiotic rat studies and the cross-circulation experiments in pigs. In these experiments, paired animals are either cross-circulated with each other's blood on a continual (the rat) or intermittent (the pig) basis. When one animal in the pairing undergoes a small bowel resection, mucosal adaptation is seen in both the resected animal and its partner $(56,57)$.

The search for the elusive humoral factor has led through a number of hormones from the gut and elsewhere. Initial investigations centred around the hormone gastrin, as many authors felt that this was the trophic hormone of the gut $(58,59)$. The observation of elevated gastrin levels in animal models of short bowel syndrome suggested an indirect association (60). Yet gastric hypersecretion and hypergastrinemia were not found universally, and several studies demonstrated a lack of correlation between levels of serum gastrin and observed intestinal adaptation $(61,62)$. Furthermore, there was no hyperplasia observed in patients with ZollingerEllison syndrome or pernicious anemia, conditions which have high serum gastrin levels. It is now felt that the trophic effects of gastrin are limited to gastric and duodenal mucosal growth with little or no effect on small intestinal adaptation $(62,63)$.

Cholecystokinin and secretin have also been postulated as possible intestinal trophic factors $(21,33)$. Unfortunately, it is difficult to separate the direct effects of these hormones from those of the pancreaticobiliary secretions which they stimulate. Exogenous cholecystokinin and secretin given to dogs maintained on total parenteral nutrition prevented the intestinal hypoplasia which normally occurs on total parenteral nutrition (64). Weser et al (65) in trying to delineate which hormone was more important, found that cholecystokinin given alone in parenterally fed rats was the trophic hormone in the cholecystokininsecretin mixture. However, in another experiment, Hughs (66) gave synthetic cholecystokinin octapeptide to rats in a high and low dosage scheme only to find that there was no effect on the intestinal mucosa in either case but a marked effect on pancreatic growth. The divergent results with cholecystokinin may relate to differences in amino acid sequence between synthetic and natural fragments examined.

Prolactin has also been investigated as a prospective agent due to the mucosal hyperplasia seen with lactating rats. Muller (67) used two models of hyperprolactinemia and, in the face of mammary hyperplasia and documented hyperprolactinemia, found no change in villus height, crypt depth, mucosal wet weight or DNA content per unit length of intestine.
Hormone profiles in models of intestinal adaptation have consistently shown elevation of the hormone enteroglucagon $(68-70)$. Enteroglucagon, though structurally similar to pancreatic glucagon, is produced in the intestine with maximal concentrations in the ileum and the colon $(54,71)$. A classic case report by Gleeson et al in 1971 (72) demonstrated intestinal mucosal hyperplasia in a patient with a renal cell enteroglucagon-secreting tumour. Following surgical removal of the tumour and return to normal enteroglucagon levels, the patient's intestinal mucosa reverted to normal (73). Experiments by Bloom and Dowling (21) in rats with extracts made from the tumour confirmed that the tumour products caused mucosal hypertrophy. Jacobs et al (74) examined enteroglucagon levels in three models of rat intestinal adaptation: resection, lactation and cold-induced hyperphagia.

In all cases the concentration of enteroglucagon was greatest in the ileal mucosa. When enteroglucagon concentration was expressed as quantity per unit weight of mucosa, there was also a marked increase. This suggests that either there were more enteroglucagon-producing cells in the intestine, or the cells were making enteroglucagon at an increased rate.

The definitive proof for a trophic effect of enteroglucagon resides in the ability of pharmacological doses to promote intestinal adaptation. Several experiments have been performed thus far with singularly disappointing results (75). It may be that enteroglucagon is not the trophic hormone but has a permissive effect on the adaptive process.

Other hormones examined as potential mediators of adaptation include epidermal growth factor, vasoactive intestinal peptide, peptide YY and the trophic peptide polyamines: putrescine, spermidine and spermine (76-78). Only the latter family of compounds have been shown to correlate with the adaptive phenomena. The enzyme ornithine decarboxylase seems to be activated by adaptation and is the rate-limiting step in the synthesis of polyamines. The role and importance of these peptides in in- 
testinal adaptation is unknown at the present time.

Pancreaticobiliary secretions: Some of the effects of pancreaticobiliary secretion have been outlined in the previous section on the hormones cholecystokinin and secretin. It is not known whether the effect of pancreaticobiliary secretion is separate from the effect of these hormones (79). Original studies by Altman and Leblond ( 80 ), in which bile and pancreatic secretions were diverted to isolated loops of ileum, demonstrated mucosal hyperplasia with increases in villus size. Later experiments with the intraluminal infusion of previously isolated pancreatic juice showed a trophic mucosal effect (81). The adaptation seen in these early experiments are now felt to be due to the protein load given intraluminally and are explained by the effects of luminal nutrition.

Experiments with pancreaticobiliary diversion in rats showed that post resectional ileal hyperplasia could be further enhanced by pancreaticobiliary diversion to the midpoint in the intestine $(80,81)$. Unfortunately, the expected hypoplasia of the proximal jejunum did not happen and, in fact, the mucosa became somewhat hyperplastic with increases in villus height, mucosal mass and absorptive surface area. These latter observations have cast some doubt on the relative importance of pancreaticobiliary secretion in the adaptive process. Most authors feel that although there is no question as to the trophic effects of pancreaticobiliary secretion on the pancreas, the effects on the intestine are minimal and of little consequence in intestinal adaptation $(79,82-84)$.

Other factors: Several other factors have been looked into as possible mediators of adaptation (21). Changes in mucosal bloodflow may be the final common pathway to all the changes of adaptation. LaPlace (85) demonstrated the abolishment of the adaptive response to partial bowel resection after vagotomy in a pig model, but little else is known of the role neural factors play. Also of interest is the effect of changing luminal bacterial flora, and additional trophic factors from the saliva, stomach and duodenum (33). Further investigation is needed to determine the relative importance of these factors.

\section{TREATMENT}

Aside from malnutrition and weight loss there are many metabolic complications which may arise from the short bowel syndrome. These include gastric hypersecretion (86), watery diarrhea, malabsorption of fat and the fat-soluble vitamins with accompanying steatorrhea, hypokalemia and renal and oxalate stone formation (87-89), divalent cation deficiencies (calcium, magnesium and zinc) (90), formation of lithogenic bile with cholesterol gallstone formation (91-93), essential fatty acid deficiency (1) and vitamin $B_{12}$ deficiency. The individual clinical picture is, therefore, variable both in its form and severity.

Both medical and surgical treatment of short bowel syndrome have been designed to control or improve three basic pathophysiological defects: decreased mucosal absorptive surface area, gastric hypersecretion, and decreased intestinal transit time. Most forms of treatment are supportive while the process of intestinal adaptation is occurring. Nevertheless, recent forms of treatment are being developed to enhance intestinal adaptation as well.

Medical treatment is designed to directly address gastric hypersecretion and decreased intestinal transit time. Indirectly, it addresses the loss of intestinal absorptive surface area by the addition of ancillary nutritional support.

Increasing effective absorption: The loss of effective mucosal absorptive surface area underlies most of the signs and symptoms of short bowel syndrome.

Perhaps the greatest advance in supportive therapy of short bowel syndrome has been the introduction of total parenteral nutrition (10-12,94). Total parenteral nutrition allows provision of calories to a patient unable to tolerate oral feeding and is responsible for the increase in patient survival with short bowel syndrome. It provides time while intestinal adaptation occurs, and in the case of extreme short bowel can provide all calories and nutrients indefinitely $(94,95)$. Total parenteral nutrition is not without its problems. Venous access on a long term basis may be difficult due to recurrent sepsis and venous obstruction (94). Also, long term total parenteral nutrition especially in the pediatric population leads to liver failure from cholestasis $(96,97)$. At present, the main causes of death in the pediatric short bowel population are sepsis and liver failure secondary to total parenteral nutrition (97).

The recognition that luminal nutrition is necessary for the adaptive response to resection has made the use of low residue, partially hydrolyzed, high caloric oral feeds an integral part of the treatment of short bowel syndrome. This is one of the few treatments which can be classified as both supportive and enhancing intestinal adaptation. To effect maximal adaptation, patients should be started on oral feeds as soon as they can be tolerated, even if only a small part of the total caloric intake is consumed in this manner. There is no agreement as to the actual composition of the oral diet. A high carbohydrate and protein diet has generally been recommended due to the severe malabsorption of complex dietary fats.

Unfortunately, much of the early work was done in uncontrolled situations and the osmotic effect of high carbohydrate diets was not appreciated. Some authors have recently shown that the restriction of fat may not be as im. portant as once believed $(98,99)$. Studies by Woolf et al (100) on eight patients with short bowel syndrome comparing high carbohydrate and high fat diets showed no difference in the absorption of fluid, electrolytes, divalent cations or calories. In an ex. tension of this work, they demonstrated that patients stabilized for one year on an oral diet do not need to restrict fat intake. There was virtually no difference in the malabsorption of fat, carbohydrate, protein or total calories on a controlled test diet containing $46 \%$ of total calories as fat (100). They do sug. gest, however, that oral intake should be increased to 35 to $40 \mathrm{kcal} / \mathrm{kg}$ of body weight and that the divalent cations (calcium, magnesium and zinc) require oral supplementation due to increased 
intestinal losses. Lactose intolerance is common in short bowel syndrome, and patients should be advised to limit exposure to milk products. Mineral and vitamin supplements are required in nearly all cases (87). Recently, it has been demonstrated that both jejunal and colonic uptake of hexoses and lipids can be modified by variations in the fat content of the diet (101-103). Whether these dietary manipulations will prove to be of benefit in humans with short bowel syndrome remains to be determined.

When there has been a significant loss of ileal length, bile acids cannot be re-absorbed in the distal ileum and thus are lost to the colon. This loss of bile acids has two consequences. First, if increased bile acid synthesis in the liver cannot compensate for bile acid loss, then a decrease in luminal concentration of bile acids results in impaired micellar formation and subsequent diminished fat absorption. In this case, oral bile acid supplementation may increase the size of the bile salt pool (87). Second, the presence of bile acids in the colon has a direct stimulatory effect on watersecretion by colonic mucosa. This choleretic diarrhea can be treated with cholestyramine, which binds bile acids in the lumen, decreasing their secretory activity in the colon (104-107).

Decreasing gastric hypersecretion: The increase in gastric secretion after extensive intestinal resection has been described for many years in animal and human models. Initial observations in humans came from the surgical literature where patients with previous vagotomies and gastrectomies for ulcers did better than others after extensive bowel resection $(108,109)$. Subsequently, gastric hypersecretion has not been shown in humans universally, and many authors doubt its existence or feel that it is only a temporary problem $(86,104)$. Certainly, the high levels of gastrin seen postoperatively do not correlate with levels of gastric secretion (110,111).

The introduction of $\mathrm{H}_{2}$ receptor antagonists has made surgical treatment of gastric hypersecretion obsolete. Studies have shown both cimetidine $(112-115)$ and ranitidine (116) to be effective in controlling gastric hypersecretion associated with short bowel syndrome.

Cimetidine may also have an effect on intestinal adaptation completely separate from its effect on gastric secretion. Studies by Cortot et al (117) show an increase in nutrient absorption with cimetidine in patients with short bowel syndrome. Cimetidine has also been shown to increase villus length and reduce steatorrhea (118). It has been postulated that the effects of cimetidine are a consequence of enhanced crypt cell production rate or a direct trophic effect on the bowel; however, neither theory has been proven conclusively $(119,120)$

Slowing intestinal transit: The increase in intestinal transit time associated with short bowel syndrome is due both to a loss of intestinal length and an alteration in intestinal motility. The resultant loss of contact time with the absorptive mucosal surfaces and digestive enzymes causes further compromise of intestinal digestion and absorption of nutrients. Medical therapy designed to decrease intestinal motility has, in the past, been based on narcotics or narcotic analogues such as codeine and diphenoxylate. These drugs act directly on intestinal smooth muscle to decrease peristalsis. Recently, loperamide has been shown to be as effective as codeine in altering intestinal transit with far fewer side effects. It appears to act by increasing nonpropulsive motor activity in both the fasting and postprandial states, enhancing retention of chyme within the small bowel (121-123).

Somatostatin is one of the major inhibitory hormones of the gut and has a marked effect on gastric secretion through direct inhibition of both gastrin and intestinal motility (124). Long acting synthetic somatostatin analogues have been shown to increase intestinal transit time and have been used to decrease diarrhea and ileostomy outputs $(125,126)$. Unfortunately, the effect of somatostatin analogues appears to be only transient (127). Furthermore, a study by Holmes (128) in rats demonstrated that somatostatin has an inhibitory effect on the hyper- plastic response to ileal resection and inhibits nutrient absorption. For these reasons, somatostatin has limited use in short bowel syndrome at present.

\section{CONCLUSIONS}

Although the factors which influence intestinal adaptation after massive intestinal resection are well known, their relative contributions to the final clinical picture are not clear. Furthermore, no single theory adequately explains the mechanism of intestinal adaptation. More than likely, several mechanisms are at work. With this gap in knowledge, it is not surprising that medical therapy to this point has been relatively ineffective in manipulating intestinal adaptation. Present therapy is supportive, controlling symptoms which arise from the basic pathophysiologic defects of short bowel syndrome: decreased intestinal transit time, gastric hypersecretion, and reduced mucosal surface area. Until there is a better understanding of the mechanisms of intestinal adaptation in short bowel syndrome, allowing active intervention, the clinician will be forced to rely largely on the intrinsic ability of the residual intestine to adapt.

ACKNOWLEDGEMENTS: Dr Fedorak is the recipient of a Clinical Investigatorship from the Alberta Heritage Foundation for Medical Research. This work is supported by a grant from the Alberta Heritage Foundation for Medical Research and the Department of Surgery, University of Alberta. The authors express appreciation to Mrs Michel Pollard for her expert secretarial assistance.

\section{REFERENCES}

1. Weser E, Fletcher JJ, Urban E. Short bowel syndrome. Gastroenterology 1979;77:572-9.

2. Tilson MD. Pathophysiology and treatment of short bowel syndrome. Surg Clin 1980;60:1273-84.

3. Cooper A, Floyd TF, Ross AJ, Bishop $\mathrm{HC}$, Templeton JM, Ziegler MM. Morbidity and mortality of short bowel syndrome acquired in infancy: An update. J Pediatr Surg 1984;19:711-7.

4. Grosfeld JL, Rescorla FJ, West KW. Short bowel syndrome in infancy and childhood. Analysis of survival in 60 patients. Am J Surg 1988;151:41-6.

5. Kristensen M, Lenz K, Nielson OV, Jarnum S. Short bowel syndrome fol- 
lowing resection for Crohn's disease. Scand J Gastroenterol 1974;9:559-65.

6. Scheflan M, Galli SJ, Perrotto J, Fischer JE. Intestinal adaptation after extensive resection of the small intestine and prolonged administration of parenteral nutrition. Surg Gynecol Obstet 1976;143:757-62.

7. Haymond HE. Massive resection of the small intestine: An analysis of 257 collected cases. Surg Gynecol Obstet 1935;61:693-703.

8. Pullan JM. Massive intestinal resection. Proc R Soc Med 1959;52:31-7.

9. Caniano DA, Kanoti GA. Newborns with massive intestinal loss: Difficult choices. N Engl J Med 1988;318:703-7.

10. Dorney SF, Ament ME, Berquist WE, Vargus JH, Hassall E. Improved survival in very short small bowel of infancy with use of long-term parenteral nutrition. J Pediatr 1985;107:521-5.

11. Taylor CJ, Manning D. Home parenteral nutrition in infantile short bowel syndrome. Acta Paediatr Scand 1986;75:866-7.

12. Ricour C, Duhamel FJ, ArnardBattandier F, Collard Y, Revillon Y, Nihoil-Fekete C. Enteral and parenteral nutrition in the short bowel syndrome in children. World J Surg 1985;9:310-5.

13. Breen KJ, McDonald IA, Panelli D, Ihle B. Planned pregnancy in a patient who was receiving home parenteral nutrition. Med J Aust 1987;146:215-7.

14. Benson CD, Lloyd JR, Krabbenhoft $\mathrm{KL}$. The surgical and metabolic aspects of massive small bowel resection in the newborn. J Pediatr Surg 1967;2:227-40.

15. Anderson CM. Long term survival with six inches of small intestine. Br Med J 1965;1:419-22.

16. Kurz R, Sauer H. Treatment and metabolic findings in extreme short bowel syndrome with $11 \mathrm{~cm}$ jejunal remnant. J Pediatr Surg 1983;18:257-63.

17. Wilmore DW. Factors correlating with a successful outcome following extensive intestinal resection in newborn infants. J Pediatr 1972;80:88-95.

18. Bristol JB, Williamson RCN. Postoperative adaptation of the small intestine. World J Surg 1985;9:825-32.

19. Hanson WR, Osborne JW, Sharp JG. Compensation by the residual intestine resection in the rat. I. Influence of amount of tissue removed. Gastroenterology 1977;72:692-700.

20. Rickham PP, Irving I, Shmerling DH. Long-term results following extensive small intestinal resection in the neonatal period. Prog Pediatr Surg 1976;10:65-75.

21. Dowling RH. Small bowel adaptation and its regulation. Scand J Gastroenterol 1982;17:53-74.
22. Nygaard K. Resection of the small intestine in rats. Nutritional status and adaptation of fat and protein absorption. Acta Chir Scand 1966;132:731. 42.

23. Hanson WR, Osborne JW, Sharp JG. Compensation by the residual intestine after intestinal resection in the rat. II. Influence of postoperative time interval. Gastroenterology 1977;72:701-5.

24. Senn N. An experimental contribution to intestinal surgery with special reference to the treatment of intestinal obstruction. Ann Surg 1888;7:99-115.

25. Flint JM.The effect of extensive resections of the small intestine. Bull John Hopkins Hosp 1912;23:127-43.

26. Clatworthy HW Jr, Saleeby R, Lovingood C. Extensive small bowel resection in young dogs: Its effect on growth and development. Surgery 1952; 72:341-9.

27. Dowling RH, Booth CC. Structural and functional changes following small intestinal resection in the rat. Clin Sci 1967;32:139-49.

28. Nygaard K. Resection of the small intestine in rats. Morphological change in the intestinal tract. Acta Clin Scand 1967;133:233-48.

29. Weser E, Hernandez MH. Studies of small bowel adaptation after intestinal resection in the rat. Gastroenterology1971;68:69-75.

30. Porus RL. Epithelial hyperplasia following massive small bowel resection in man. Gastroenterology 1965;48:753-7.

31. Menge H, Robinson JWL. The relationship between functional and structural alterations in the rat small intestine following proximal resection of varying extents. Res Exp Med 1978;173:41-53.

32. Williamson RCN. Adaptive intestinal hyperplasia. In: Batt R, Lawrence TLS, eds. Function and dysfunction of the small intestine. Liverpool: Liverpool University Press, 1984:55-76.

33. Williamson RCN. Intestinal adaptation structural, functional and cytokinetic changes. N Engl J Med 1978;308:1303-403,1444-50.

34. Bochkov NP. Morphological changes in the jejunum and ileum of rats after wide resection of the small intestine. Bull Exp Biol Med 1959;47:339-43.

35. Wright NA. The experimental analysis of changes in proliferative and morphological status in studies on the intestine. Scand J Gastroenterol 1982;17:3-21

36. Weinstein LD, Shoemaker CP, Hersh T, Wright HK. Enhanced intestinal absorption after small bowel resection in man. Arch Surg 1969;99:560-2.

37. Dowling RH, Booth CC. Functional compensation after small bowel resec- tion in man. Demonstration by direct measurement. Lancet 1966;ii:146-7.

38. McCarthy DM, Kim YS. Changes in sucrase, enterokinase, and peptide hydrolase after intestinal resection. The association of cellular hyperplasia and adaptation. J Clin Invest 1973;52:942-51.

39. Karasov WH, Diamond JM. Adaptive regulation of sugar and amino acid transport by vertebrate intestine. Am J Physiol 1983;245:G443-62.

40. Bury KD. Carbohydrate digestion and absorption after massive resection of the small intestine. Surg Gynecol Obstet 1972;135:177-87.

41. Rudo N, Deveney CW, Way LW. Ilea adaptation following proximal intestinal resection is characterized by decreased cellular uptake of amino acid. J Surg Res 1979;26:542-6.

42. Gutschmidt S, Kaul W, Menge H, Riecken EO. The adaptive response of disaccharidase activities at different sites along the villus epithelium after proximal intestinal resection inthe rat. Res Exp Med 1983;182:203-13.

43. Keelan M, Walker K, Thomson ABR Resection of rabbit ileum: Effect on brush border membrane enzyme markers on lipids. Can J Physiol Pharmacol 1985;63:1528-32.

44. Gleeson MH, Gullen J, Dowling RH. Intestinal structure and function after small bowel by-pass in the rat. Clin Sci 1972;43:731-42.

45. Richter HM, Kelly KA. Effect of transsection and pacing on human jejunal pacesetter potentials. Gastroenterology 1986;91:1380-5.

46. Snell AM, Camp JD. Chronic idiopathic steatorrhea: Roentgenologic observations. Ann Intern Med 1934;53:615-29.

47. Spiller RC, Trotman IF, Higgins BE et al. The ileal brake - Inhibition of jejunal motility after ileal fat perfusion in man. Gut 1984;25:365-74

48. Feldman EJ, Dowling RH, McNaughton J, Peters TJ. Effects of oral versus intravenous nutrition on intestinal adaptation after small bowel resection. Gastroenterology 1976;70:712-9.

49. Shin CS, Chaudhry AG, Khaddam $\mathrm{MH}$, Penha PD, Dooner R. Early morphologic changes in the intestine following massive resection of the small intestine and parenteral nutrition therapy. Surg Gynecol Obstet 1980;151:246-50.

50. Hughes CA, Ducker DA. The effect of enteral nutrition on the gut and pancreas after total parenteral nutrition. In: Robinson JWL, Dowling RH, Riecken EO, eds. Mechanisms of intestinal adaptation. Lancaster: MTP Press, 1982:173-4. 
51. Gleeson MW, Dowling KH, Peter T]. Biochemical changes in intestinal mucosa after experimental small bowel by-pass in rats. Clin Sci 1972;43:743-57.

52. Jacobs LR, Taylor BR, Dowling RH. Effect of luminal nutrition on the intestinal adaptation following Thiry-Vella by-pass in the dog. Clin Sci Mol Med 1975;49:26P-7P. (Abst)

53. Morin CL, Grey VL, Garofalo C. Influence of lipids on intestinal adaptation after resection. In: Robinson JWL, Dowling RH, Riecken EO, eds. Mechanisms of Intestinal Adaptation. Lancaster: MTP Press, 1982:175-84.

54. Miazza BM, Al-Mukhtar MYT, Salmeron M, et al. Hyperenteroglucagonaemia and small intestinal mucosal growth after colonic perfusion of glucose in rats. Gut 1985;26:518-24

55. Williamson RCN, Malt RA. Humoral modulation of compensatory intestinal hyperplasia. In: Robinson FWL, Dowling RH, Riecken EO, eds. Mechanisms of Intestinal Adaptation. Lancaster: MTP Press, 1982:215-24.

56. Williamson RCN, Buchholtz TW, Malt RA. Humoral stimulation of cell proliferation in small bowel after transsection and resection in rats. Gastroenterology 1978;75:249-54.

57. LaPlace JP. Intestinal resection in chronically blood crossed twin pigs: Blood carried factor(s). Digestion 1979;10:229.

58. Johnson LR, Lichtenberger LM, Copeland EM, Dudrick SJ, Castro GA. Action of gastrin on gastrointestinal structure and function. Gastroenterology 1975;68:1184-92.

59. Johnson LR. The trophic action of gastrointestinal hormones. Gastroenterology 1976;70:278-88.

60. Straus E, Gerson CD, Yalow RS. Hypersecretion of gastrin associated with the short bowel syndrome. Gastroenterology 1974;66:175-80.

61. Oscarson JEA, Veen HF, Williamson RCN, Ross JS, Malt RA. Compensatory post-resectional hyperplasia and starvation atrophy in small bowel: Dissociation from endogenous gastrin levels. Gastroenterology 1977;72:890-5.

62. Mayston PD, Barrowman JA, Dowling RH. Effect of pentagastrin on small bowel structure and function in the rat. Digestion 1975;12:78-84.

63. Johnson LR. Role of gastrointestinal peptides in intestinal adaptation. In: Robinson JWL, Dowling RH, Riecken EO, eds. Mechanisms of Intestinal Adaptation. Lancaster: MTP Press, 1982:201-11.

64. Hughes CA, Bates T, Dowling RH. Cholecystokinin and secretin prevent the intestinal mucosal hypoplasia of total parenteral nutrition in the dog. Gastroenterology 1978;75:34-41.
65. Weser E, Bell D, Tawil T. Effects of octapeptide-cholecystokinin, secretin, and glucagon on intestinal mucosal growth in parenterally nourished rats. Dig Dis Sci 1981;26:409-16.

66. Hughes CA, Breuer RS, Hatoft DE, Ducken DA, Dowling RH. The effect of CCK octapeptide on the pancreas: A study in rats during total parenteral nutrition (TPN) and oral feeding. Eur J Clin Invest 1980;10:16. (Abst)

67. Muller E, Dowling RH. Prolactin and the small intestine: Effect of hyperprolactinaemia on mucosal structure in the rat. Gut 1981;22:558-65.

68. Bloom SR, Besterman HS, Adrian TE, et al. Gut hormone profile following resection of large and small bowel. Gastroenterology 1979;76:1101. (Abst)

69. Bloom SR, Polak JM. The hormonal pattern of intestinal adaptation: A major role for enteroglucagon. Scand J Gastroenterol 1982;17:93-103.

70. Sagor GR, Ghatei MA, O'Shaughnessy DJ, Al-Mukhtar MYT, Wright NA, Bloom SR. Influence of somatostatin and bombesin on plasma enteroglucagon and cell proliferation after intestinal resection in the rat. Gut 1985;26:89-94.

71. Appleton GVN, Bristol JB, Williamson RCN. Proximal enterectomy provides a stronger systemic stimulus to intestinal adaptation than distal enterectomy. Gut 1987;28:165-8.

72. Gleeson MH, Bloom SR, Polak JM, Henry K, Dowling RH. Endocrine tumour in kidney affecting small bowel structure, motility and absorptive function. Gut 1972;12:773-82.

73. Bloom SR. An enteroglucagon tumour. Gut 1972;13:520-3.

74. Jacobs LR, Bloom SR, Dowling RH. Response of plasma and tissue levels of enteroglucagon immunoreactivity to intestinal resection, lactation and hyperphagia. Life Sci 1981;29:2003-7.

75. Bloom SR. Gut hormones in adaptation. Gut 1987;28:31-5.

76. Lezoche E, Carlei F, Vagni F, Mora GV, Speranza V. Elevated plasma levels of vasoactive intestinal polypeptide in short bowel syndrome. Am J Surg 1983;145:369-70.

77. Adrian TE, Savage AP, Fuessl HS, Wolfe K, Besteran HS, Bloom SR. Release of peptide YY (PYY) after resection of small bowel, colon, or pancreas in man. Surgery 1987;101:715-9.

78. Dowling RH, Hosomi M, Stace NN, et al. Hormones and polyamines in intestinal and pancreatic adaptation. Scand J Gastroenterol 1985;20:84-95.

79. Miazza BM, Levan van Hung, Vaja S, Dowling RH. Effect of pancreaticobiliary diversion (PBD) on jejunal and ileal structure and function in the rat. In: Robinson JWL, Dowling RE, Riecken EO, eds. Mechanisms of Intestinal Adaptation. Lancaster: MTP Press, 1982:467-77.

80. Altmann GG. Influence of bile and pancreatic secretions on the size of the intestinal villi in the rat. Am J Anat 1971;132:167-78.

81. Williamson RCN, Vauer FLR, Ross JS, Malt RA. Contributions of bile and pancreatic juice to cell proliferation in ileal mucosa. Surgery 1978;83:570-6.

82. Weser E, Heller R, Tawil T. Stimulation of mucosal growth in the rat ileum by bile and pancreatic secretions after jejunal resection. Gastroenterology 1977;73:524-9.

83. Miazza BM, Levan V, Ghatei M, Adrian T, Bloom SR, Dowling RH. Role of regulatory peptides in the small bowel and pancreatic adaptation of pancreatico-biliary diversion (PBD) following jejunal of ileal transposition in the rat. Eur J Clin Invest 1982;1227. (Abst)

84. Al-Mukhtar MYT, Sagor GR, Ghatei MA, Bloom SR, Wright NA. The role of pancreatico-biliary secretions in intestinal adaptation after resection and its relationship to plasma enteroglucagon. Br J Surg 1983;70:398-400.

85. Laplace JP. Intestinal motility. In: Robinson JWL, Dowling RH, Riecken $\mathrm{EO}$, eds. Mechanisms of Intestinal Adaptation. Lancaster: MTP Press, 1982:321-31.

86. Windsor CWO, Fejfar J, Woodward DAK. Gastric secretion after massive small bowel resection. Gut 1969;10:779-86.

87. Jeejeebhoy KN. Therapy of the short gut syndrome. Lancet 1983;i:1427-30.

88. Badley BWD, Murphy GM, Rouchier IAD. Intraluminal bile salt deficiency in the pathogenesis of steatorrhea. Lancet 1969;ii:400-2.

89. Chadwick VS, Modha K, Dowling LH. The mechanism for hyperoxaluria in patients with ileal dysfunction. N Engl J Med 1973;289:172-6.

90. Woolf GM, Miller C, Kurian R, Jeejeebhoy KN. Nutritional absorption in short bowel syndrome. Evaluation of fluid, calorie and divalent cation requirement. Dig Dis Sci 1987;32:8-15.

91. Dowling RE, Bell GD, White J, Lithogenic bile in patients with ileal dysfunction. Gut 1972;13:415-20.

92. Heaton KW, Read AE. Gallstones in patients with disorders of the terminal ileum and disturbed bile salt metabolism. Br Med J 1969;3:494-6.

93. Perry M, White J, Dowling RH. Bile acid absorption by jejunum and colon after ileal resection in the rat. $\mathrm{Br}$ J Surg 1972;59:310. (Abst)

94. Dudrick SJ, O'Donnell JJ, Englert DM, 
et al. 100 patient years of ambulatory home total parenteral nutrition. Ann Surg 1984;199:770-81.

95. Wilmore DW, Dudrick SJ, Daly JM, Vars WM. The role of nutrition in the adaptation of the small intestine after massive resection. Surg Gynecol Obstet 1971;132:673-80.

96. Benjamin DR. Hepatobiliary dysfunction in infants and children associated with long term total parenteral nutrition. A clinicalpathologic study. Am J Clin Pathol $1981 ; 76: 276-83$.

97. Hodes JE, Grosfeld JL, Weber TR, Schreiner RL, Fitzgerald FJ, Mirkin LD. Hepatic failure in infants on total parenteral nutrition (TPN): Clinical and histopathologic observations. J Pediatr Surg 1982;17:463-8.

98. Bochenek W, Rodgers JB, Balint JA. Effects of changes in dietary lipids on intestinal fluid loss in the short bowel syndrome. Ann Intern Med 1970;72:205-13.

99. McIntyre PB, Fitchew M, LennardJones JE. Patients with a high jejunostomy do not need a special diet. Gastroenterology 1986;91:25-33.

100. Woolf GM, Miller C, Kurian R, Jeejeebhoy KN. Diet for patients with a short bowel: High fat or high carbohydrate? Gastroenterology $1983 ; 84: 823-8$

101. Thomson ABR, McIntyre Y, MacLeod J, Keelan M. Dietary fat content influences uptake of hexoses and lipids into rabbit jejunum following ileal resection. Digestion 1986;35:7888.

102. Thomson ABR, McIntyre Y, MacLeod J, Keelan M. Adaptation of colonic uptake of hexoses and lipids following ileal resection: Effect of variations in the fat content of the diet. Digestion 1986;35:89-94

103. Thomson ABR, Keelan M. Isocal ${ }^{\circledR}$ and Portagen ${ }^{\circledR}$ alter intestinal uptake of sugars but not mucosal surface area in rabbits with an intact intestinal tract and following ileal resection. Clin Invest Med 1987;10:520-9.

104. Playoust MR, Lack L, Weiner IM. Effect of intestinal resection on bile salt absorption in dogs. Am J Physiol 1965;208:363-9.

105. Mekhjian HS, Phillips SF, Hofmann AF. Colonic secretion of water and electrolytes induced by bile acids:
Perfusion studies in man. J Clin Invest 1971;50:1569-77.

106. Cummings JH, James WPT, Wiggins HS. Role of the colon in ileal resection diarrhea. Lancet 1973;i:344-7.

107. Weser $E$. The management of patients after small bowel resection. Gastroenterology 1976;71:146-50.

108. Frederick PL, Sizer JS, Osborne MP. Relation of massive bowel resection to gastric secretion. N Engl J Med 1965;272:509-14.

109. Osborne MP, Frederick PL, Sizer JS, Blair D, Cole D, Thum W. Mechanism of gastric hypersecretion following massive intestinal resection-Clinical and experimental observations. Ann Surg 1966;164:622-32.

110. Williams NS, Evans P, King RFGJ. Gastric acid secretion and gastric production in the short bowel syndrome. Gut 1985;26:914-9.

111. Hyman PE, Everett SL, Harada T. Gastric acid hypersecretion in short bowel syndrome in infants: Association with extent of resection and enteral feeding. J Pediatr Gastroenterol Nutr 1986;5:191-7.

112. Doherty NJ, Sufian S, Pavlides CA, Matsumoto T. Cimetidine in the treatment of severe metabolic alkalosis secondary to short bowel syndrome. Int Surg 1978;63:140-2.

113. Murphy JP, King DR, Dubois A. Treatment of gastric hypersecretion with cimetidine in the short bowel syndrome. N Engl J Med 1979;300:80-1.

114. Aly A, Barany F, Kollberg B, Monsen U, Wisen O, Johansson C. Effect of an $\mathrm{H}_{2}$-receptor blocking agent on diarrhea after extensive small bowel resection in Crohn's disease. Acta Med Scand 1980;207:119-22.

115. Jacobsen O, Ladefoged K, Stage JG, Jarnum S. Effects of cimetidine on jejunostomy effluents in patients with severe short bowel syndrome. Scand J Gastroenterol 1986;21:824-8.

116. Hyman PE, Garvey TQ, Harada T, Ament ME. Ranitidine inhibits basal gastric acid hypersecretion in an infant with short bowel syndrome. Gastroenterology 1983:1193. (Abst)

117. Cortot A, Fleming R, Malagelada JR. Improved nutrient absorption after cimetidine in short bowel syndrome with gastric hypersecretion. $\mathrm{N}$ Engl J Med 1979;300:79-80.

118. Tomas-de la Vega JE, Banner BF,
Haklin MF, Saxon AE, Roseman DL Effect of cimetidine on intestinal adap tation following massive resection of the small intestine. Surg Gynecol Obstet 1983;156:41-50.

119. Callaghan B. An effect induced by cimetidine on crypt cell proliferation in the rat small intestine. Singapore Med J 1979;20:351-4.

120. Goldman CD, Rudloff MA, Ternberg JL. Cimetidine and neonatal small bowel adaptation: An experimental study. J Pediatr Surg 1987;22:484-7.

121. King RFGJ, Norton T, Hill GL. A double-blind crossover study of the effect of loperamide hydrochloride and codeine phosphate on ileostomy output. Aust N Z J Surg 1982;52:121-4.

122. Remington MM, Brown ML, Robertson JS, et al. Transit of solid liquid components of a meal in the short bowel syndrome quantified by total gut scintiscanning: Effect of loperamide. Gastroenterology 1981:80:1260. (Abst)

123. Remington MM, Fleming CR, Zinsmeister AR, Malagelada JR. Gastrointestinal motility patterns in the short bowel syndrome: Effect of a synthetic opiate. Gastroenterology 1981;80:1260. (Abst)

124. Krejs GJ. Physiological role of somatostatin in the digestive tract: Gastric acid secretion, intestinal absorption and motility. Scand J Gastroenterol 1986;21:47-53.

125. Ohlbaum P, Galperine RI, Demarquez JL, Vergnes P, Martin C. Use of a long-acting somatostatin analogue (SMS 201-995) in controlling a significant ileal output in a 5 year old child. J Pediatr Gastroenterol Nutr 1987;6:466-70.

126. Williams NS, Cooper JC, Axon ATR, King RFGJ, Carker M. Use of a long acting somatostatin analogue in controlling life threatening ileostomy diarrhea. Br Med J 1984;289:1027-8.

127. Mulvihill S, Pappas TN, Passaro E Jr, Debas HT. The use of somatostatin and its analogs in the treatment of surgical disorders. Surgery 1986;100:467. 76.

128. Holmes SJK, Jaspen JB, Moossa AR. The effect of somatostatin on post-resectional ileal hyperplasia. Endocrinology 1982:111:1397-9. 


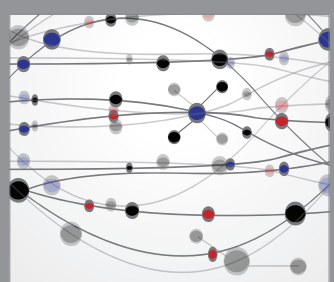

The Scientific World Journal
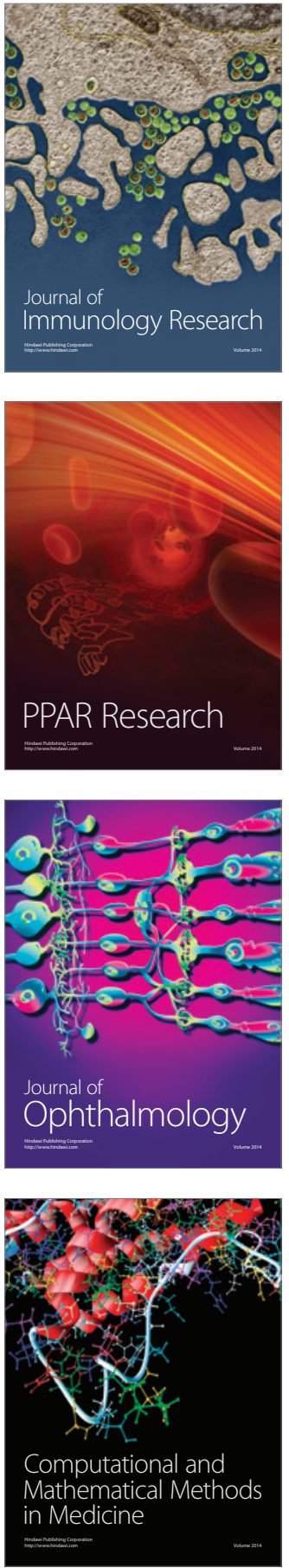

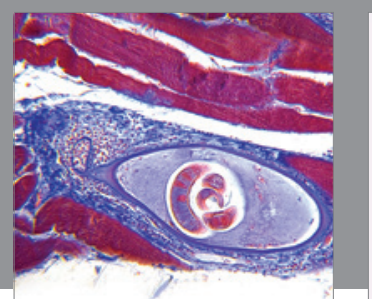

Gastroenterology Research and Practice

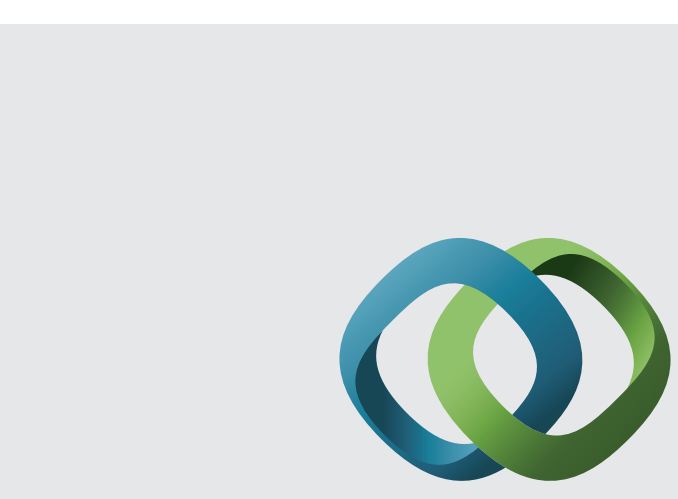

\section{Hindawi}

Submit your manuscripts at

http://www.hindawi.com
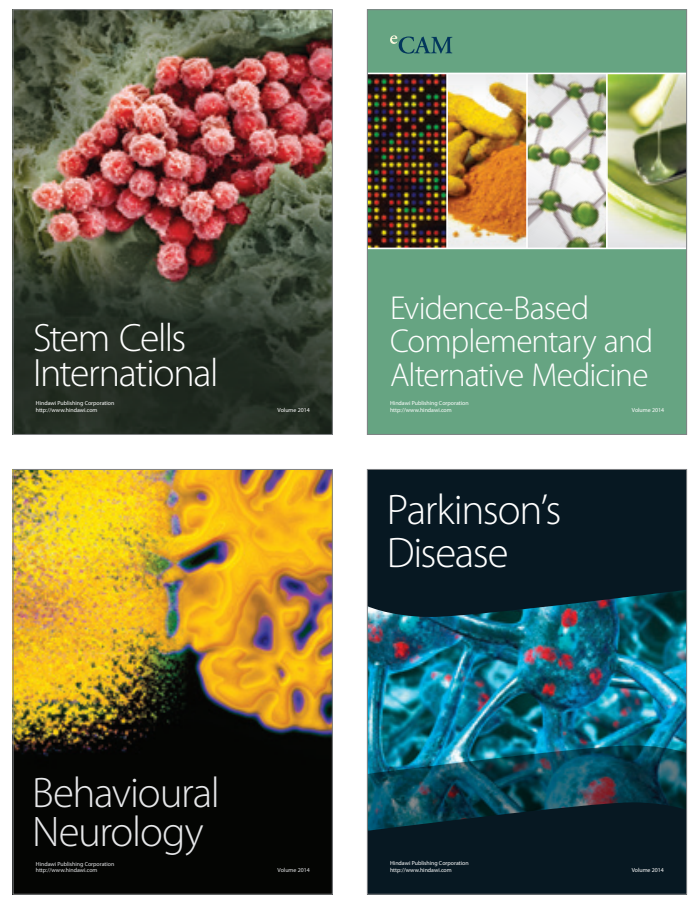
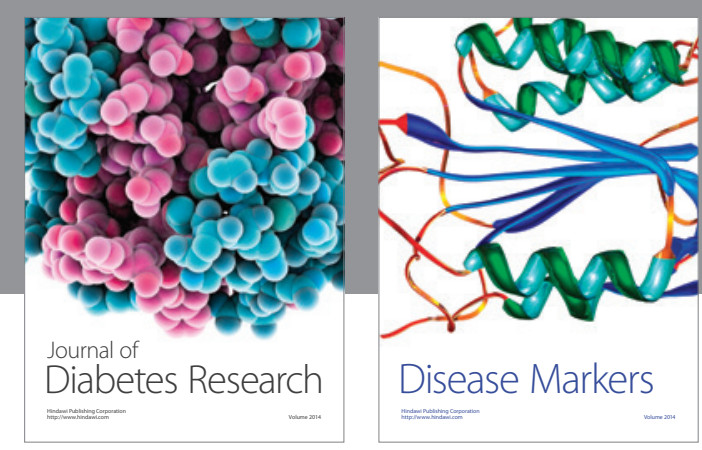

Disease Markers
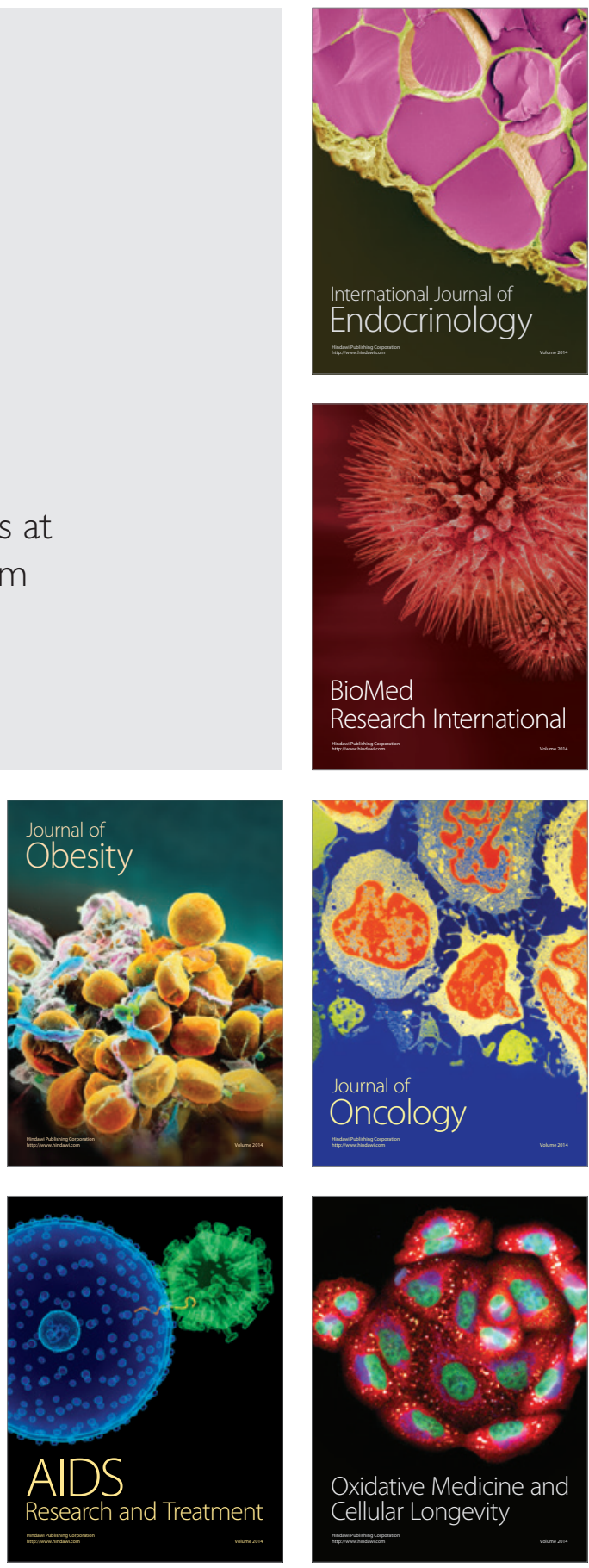